\title{
PHARMACOKINETICS OF ISONIAZID IN THE ELDERLY
}

The hepatic metabolism of many drugs seems to be diminished in the elderly. This applies, in particular, to the hydroxylation of antipyrine (O'Malley, Crooks, Duke \& Stevenson, 1971), chlormethiazole (Triggs, 1979), phenylbutazone (O'Malley et al., 1971) and quinine (Stevenson, Salem \& Shepherd, 1979). Other reactions, however, such as the demethylation of diazepam (Klotz, Avant, Hoyumpa, Schenker \& Wilkinson, 1975) or lignocaine (Triggs, 1979), the reduction of nitrazepam (Castleden \& George, 1978) and the hydroxylation of nortryptiline (Braithwaite, Montgomery \& Dawling, 1979) or warfarin (Hewick, Moreland, Shepherd \& Stevenson, 1975) do not appear to be modified.

With regard to isoniazid (INH), which is acetylated in the liver, Farah, Taylor, Rawlins \& James (1971) showed that its half-life remains unchanged in the elderly, but failed to give details of the patients' age ('over 65 years') and of other pharmacokinetic constants, though it is known that in the absence of clearance data no clear-cut interpretation of the results can be made, since differences may be related to altered drug distribution rather than impaired metabolism (Mitchard, 1979). In order to detect possible changes in the acetylation of INH, therefore, we compared the pharmacokinetics of the drug in adults below and above 60 years of age.

Ten tuberculous adults (seven men and three women) aged between 25 and 55 years (mean: $37 \pm 8$ years) and eleven elderly people (two men and nine women) aged between 64 and 100 years (mean: $84 \pm 4$ years) were selected. Patients with kidney, liver or gastrointestinal disease, or with a history of cerebral vascular accident, or on major or multiple therapy had been excluded. Three elderly, however, were under regular treatment: one with nafthydrofuryl $(150 \mathrm{mg} /$ day), another with digoxin $(0.25 \mathrm{mg}$ on alternate days) and glafenin (400 $\mathrm{mg} / \mathrm{day})$, and the third one with digoxin $(0.25 \mathrm{mg}$ on alternate days), frusemide $(20 \mathrm{mg} /$ day $)$ and diazepam ( $5 \mathrm{mg} /$ day). All subjects had haemoglobin, BUN, serum electrolytes, bilirubin, total plasma proteins and serum creatinine levels within the normal range for their age and sex. All gave free informed consent.

The subjects fasted for $12 \mathrm{~h}$ before receiving an intravenous injection of INH 5 to $7 \mathrm{mg} / \mathrm{kg}$. They continued to fast for a further $2 \mathrm{~h}$, then were allowed a light meal. No other medication was administered during the test.

In the elderly, blood samples were taken $4,8,12$, 16,20 and $30 \mathrm{~min}$, and $1,2,3,4$ and $5 \mathrm{~h}$ after the injection. In the younger patients, samples were taken at $3 \mathrm{~min}$ intervals during $45 \mathrm{~min}$ and $1,1.25,1.5,2$, $2.5,3,4$ and $6 \mathrm{~h}$ after the injection. Blood samples
$(0.5 \mathrm{ml})$ were collected into heparinized tubes, and INH assays were immediately performed. INH concentrations in the serum were measured by the spectrofluorimetric method of Thénault, Saltiel, Houin, Vivien, Tillement \& Chrétien (1976), adapted from Scott \& Wright (1967) and Boxenbaum \& Riegelman (1974).

The plasma isoniazid concentration data were subjected to an open two-compartments model analysis on a techtronic microcomputer type 4051, according to Wagner's (1975) equations. Comparisons between the two groups were made by means of Student's $t$-test for unpaired data.

The results are given in Table 1.

Fast acetylators were considered as having an INH half-life shorter, and slow acetylators longer than 110 min (Weber \& Hein, 1979).

The significant differences in plasma elimination half-life, area under the curve and plasma total clearance between fast and slow acetylators in both age-groups reflect the bimodal distribution of acetylator populations (Evans, Manley \& McKusick, 1960), also found with other drugs, such as procainamide, hydralazine, dapsone and many sulphonamides.

The lack of significant differences in distribution volumes or constants between young and elderly subjects and for the same type of acetylator could be due in theory to non-hepatic factors, such as changes in digestive tract absorption, reduced renal excretion or reduced diffusion of the drug, that would modify the pharmacokinetics of isoniazid in the elderly, increase the blood levels and mask an increase in hepatic metabolism rate. However: (a) in this study INH was administered intravenously; (b) in both 'fast' and 'slow' acetylators the percentage of INH conjugated in the liver is very high (Weber \& Hein, 1979) and the metabolism of the drug is not substantially modified by renal impairment (Bowersox, Winterbauer, Stewart, Orme \& Barron, 1973; Gold, Buchanan, Tringham, Viljoen, Strickwold \& Moodley, 1976); (c) contrary to other drugs, such as digoxin (Ewy, Kapadia, Yao, Lullin \& Marcus, 1975), propicillin K (Simon, Malerczyk, Müller \& Müller, 1972) or diazepam (Klotz et al., 1975), the diffusion of INH in the body is not reduced in the elderly, since distribution volumes and constants remain the same as in younger adults.

It may therefore reasonably be suggested that the activity of the genetically controlled polymorphic Nacetyltransferase responsible for hepatic acetylation is preserved in the ageing process up to an advanced age ( 95 to 100 years), though this could only be proven by liver biopsies. 
Table 1 Pharmacokinetics of isoniazid in subjects under $(n=11)$ and over $(n=10) 60$ years of age and in fast and slow acetylators. Each value represents the mean \pm s.d.



$\alpha$ : distribution constant rate; $T_{\frac{1}{2}} \alpha$ : distribution half-life; $\beta$ : plasma elimination constant rate; $T_{1} \beta$ : plasma elimination half-life; $\mathrm{K}_{\mathrm{el}}$ : elimination constant rate; $\mathrm{K}_{21}$ : microconstant from the peripheral to central compartment; $\mathrm{K}_{12}$ : microconstant from the central to the peripheral compartment; $\mathrm{V}_{1}$ : apparent volume of the central compartment; $\mathrm{V}_{2}$ : apparent volume of the peripheral compartment; AUC: area under the serum concentration curve; $\mathrm{Cl}$ : plasma total clearance.

Statistical differences between fast and slow acetylators are indicated as: ${ }^{*}=P<0.05 ; \dagger=P<0.01$.

The persisting acetylation of INH may be compared with other phase II metabolic reactions, such as the glycine conjugation of aspirin (Stevenson et al., 1971), or the glucuronide and sulphate conjugation of paracetamol (Triggs, Nation, Long \& Ashley, 1975), which also remain unchanged with age, and contrasted with the phase I metabolic reactions mentioned in the introductory paragraph.

\section{ADVENIER \& A. SAINT-AUBIN}

Département de Pharmacologie, Faculté de Médecine
Necker-Enfants Malades, 156, rue de Vaugirard, F 75015, Paris

\section{GOBERT}

Hospice Intercommunal de Fontenay-sous-Bois, 74, avenue de Stalingrad, F 94120, Fontenay-sous-Bois

\section{G. HOUIN, E. ALBENGRES, J.P. TILLEMENT}

Département de Pharmacologie, Faculté de Médecine Paris XII, 8 rue du Général Sarrail, F 94000 Créteil

Received December 31, 1979

\section{References}

BOXENBAUM, H.G. \& RIEGELMAN, S. (1974). Determination of isoniazid and metabolites in biological fluids. J. pharm. Sci., 63, 1191-1197.

BOWERSOX, D.W., WINTERBAUER, R.H., STEWART, G.L., ORME, B. \& BARRON, E. (1973). Isoniazid dosage in patients with renal failure. New. Engl. J. Med., 89, 84-87.

BRAITHWAITE, R., MONTGOMERY, S. \& DAWLING, S. (1979). Age depression and tricyclic antidepressant levels. In Drugs and the Elderly, eds. Crooks, J. \& Stevenson, I.H. pp. 133-144. London: Macmillan.

CASTLEDEN, C.M. \& GEORGE, C.F. (1979). Increased sensitivity to benzodiazepines in the elderly. In Drugs and the Elderly, eds. Crooks, J. \& Stevenson, J.H. pp. 169-178. London: Macmillan.

EVANS, D.A.P., MANLEY, K.A. \& Mc KUSICK, V.A. (1960). Genetic control of isoniazid metabolism in man. Br. med. J., 2, 485-491.

EWY, G.A., KAPAKIA, G.G., YAO, L., LULLIN, M. \& MARCUS, F.I. (1969). Digoxin metabolism in the elderly. Circulation, $39,449-453$.

FARAH, F., TAYLOR, W., RAWLINS, M.D.\& JAMES, O. (1977). Hepatic drug acetylation and oxidation : effects of aging in man. Br. med. J., 2, 155-156.

GOLD, C.H., BUCHANAN, N., TRINGHAM, V., VILJOEN, M., STRICKWOLD, B. \& MOODLEY, G.P. (1976). Isoniazid pharmacokinetics in patients in chronic renal failure. Clinical Nephrology, 6, 365-369. 
HEWICK, D.S., MORELAND, T.A., SHEPHERD, A.M.M. \& STEVENSON, I.H. (1975). The effect of age on the sensitivity of warfarin sodium. Br. J. clin. Pharmac., 2, 189p-190P.

KLOTZ, U., AVANT, G.R., HOYUMPA, A., SCHENKER, S. \& WILKINSON, G.R. (1975). The effects of age and liver disease on the disposition and elimination of diazepam in adult man. J. clin. Invest., 55, 347-359.

MITCHARD, M. (1979). Drug distribution in the elderly. In Drugs and the Elderly, eds. Crooks, J. \& Stevenson, I.H.pp. 65-76. London: Macmillan.

O'MALLEY, K., CROOKS, K., DUKE, E. \& STEVENSON, I.H. (1971). Effect of age and sex on human drug metabolism. Br. med. J., 3, 607-609.

SCOTT, E.M. \& WRIGHT, R.C.J. (1967). Fluorometric determination of isonicotinic acid hydrazide in serum. $J$. Lab. clin. Invest., 70, 355-360.

SIMON, C., MALERCZYK, V., MƯLLER, U. \& MÚLLER, G. (1972). Zur Pharmakokinetik von propicillin bei geriatrischen patienten im vergleich zu jungeren erwachsenen. Deutsche med. Wochenschrift, 97, 1999-2003.
STEVENSON, I.H., SALEM, S.A.M. \& SHEPHERD, A.M.M. (1979). Studies on drug absorption and metabolism in the elderly. In Drugs and the Elderly, eds. Crooks, J. \& Stevenson, I.H. pp. 51-63. London: Macmillan.

THENAULT, P., SALTIEL, J.C., HOUIN, G., VIVIEN, J.N., TILLEMENT, J.P.\& CHRETIEN, J. (1976). Comparaison de deux méthodes de dosage de l'INH sérique. Etude de 50 patients. Thérapie, 31, 747-754.

TRIGGS, E.J. (1979). Pharmacokinetics of lignocaine and chlormethiazole in the elderly: with some preliminary observations on other drugs. In Drugs and the Elderly, eds. Crooks, J. \& Stevenson, I.H. pp. 117-132. London: Macmillan.

TRIGGS, E.J., NATION, R.L., LONG, A. \& ASHLEY, J.J. (1975). Pharmacokinetics in the elderly. Eur. J. clin. Pharmac., 8, 55-62.

WAGNER, J.G. (1975). Fundamentals of clinical pharmacokinetics, pp. 82-90. Hamilton:Drug Intelligence Publications.

WENER, W.W. \& HEIN, D.W. (1979). Clinical pharmacokinetics of isoniazid. Clin. Pharmacokin., 4, 401-422.

\section{EFFECT OF AGE ON PLASMA PROPRANOLOL LEVELS}

After giving a single $\mathbf{4 0} \mathrm{mg}$ oral dose of propranolol, Castleden \& George (1979) found significantly higher plasma drug levels in elderly subjects than in young, healthy volunteers. These results are similar to those described by Castleden, Kaye, \& Parsons (1975), although the mean plasma propranolol levels in the young group in the more recent paper are almost double those found in 1975 and at variance with other published data (Parsons, Kaye, Raymond, Trounce \& Turner, 1976; Schneider, Babb, Bishop, Mitchard, Hoare \& Hawkins, 1976). The elderly subjects in both cases were drawn at least in part from long-stay geriatric wards, and presumably could not be described as healthy and active. In these studies, therefore the pharmacokinetic differences from youthful controls might be attributable to age associated disease rather than to age itself.

Logically, investigation of the influence of age per se on pharmacokinetic parameters can only be carried out in elderly volunteers with no evidence of disease or drug use which might influence the results obtained. We have therefore determined the plasma propranolol concentrations obtained after single oral doses of $40 \mathrm{mg}$ and of $80 \mathrm{mg}$ propranolol in elderly (63-81 years) volunteers in excellent health who were living and in some cases working independently in the community. These results have been compared with results obtained under identical conditions in healthy active young (19-25 years) volunteers. Different volunteers were involved in the investigation of each of the $40 \mathrm{mg}$ and $80 \mathrm{mg}$ doses so that each volunteer received only one dose of propranolol. All volunteers in both young and elderly groups were non-smokers in whom no abnormality was detected on clinical examination or on biochemical or haematological profiles and who had an ESR of $<20 \mathrm{~mm} / \mathrm{h}$.

Mean plasma propranolol concentrations after the smaller dose $(40 \mathrm{mg})$ were almost identical in the two groups at all sampling times (Figure 1). The mean areas under the plasma concentration-time curves (AUC) were also similar, being $82.5 \pm 14.1$ (s.e. mean) $\mathrm{ng} \mathrm{ml}^{-1} \mathrm{~h}$ in the young group and $81.3 \pm 8.4$ (s.e. mean) $\mathrm{ng} \mathrm{ml}^{-1} \mathrm{~h}$ in the elderly group. After $80 \mathrm{mg}$, there was no difference between the peak levels of the mean plasma concentration-time curves of the young and elderly groups, although the peaks occurred at different times (Figure 2). The mean AUCs were $665 \pm 149$ (s.e. mean) $\mathrm{ng} \mathrm{ml}^{-1} \mathrm{~h}$ in the young group and $466 \pm 52$ (s.e. mean) $\mathrm{ng} \mathrm{ml}^{-1} \mathrm{~h}$ in the elderly group but this difference was not significant at the $5 \%$ level. The results of this study therefore indicate that the pharmacokinetics of oral propranolol in healthy active elderly volunteers are similar to those in healthy young volunteers.

These results are supported by a recent detailed study by Vestal, Wood, Branch, Shand \& Wilkinson (1979) on the effect of age and cigarette smoking on propranolol disposition. They stated that 'the decline in intrinsic total clearance (of propranolol) with age was critically dependent on the smoking habits of the subjects' and concluded that the drug-metabolizing capacity of non-smokers did not alter with age.

It has been the practice of most workers to describe volunteers used for drug studies as being free from 